\title{
The Application of Informal Supervision to Improve the Quality of Learning in Laboratory Schools
}

\author{
Ahmad Nurabadi \\ Department of Educational Administration \\ Universitas Negeri Malang, Indonesia \\ ahmad.nurabadi.fip@um.ac.id \\ Sucipto \\ Department of Non-Formal Education \\ Universitas Negeri Malang, Indonesia \\ sucipto.fip@um.ac.id
}

\author{
Imam Gunawan \\ Department of Educational Administration \\ Universitas Negeri Malang, Indonesia \\ imam.gunawan.fip@um.ac.id \\ Yuyik Lulita Sari \\ Department of Educational Administration \\ Universitas Negeri Malang, Indonesia \\ yuyik.lulitasarie@gmail.com
}

\begin{abstract}
Principals and teachers need to know what is really happening in the classroom in their school area. The principal and teacher must be well acquainted with all their students, guardians of students, and the community around the school. The purpose of this study is to create a model of learning supervision by using informal supervision techniques as a way to improve the quality of learning, especially improving the quality of teachers in teaching. The specific purpose of this study is to describe the implementation of informal supervision in the Laboratory of State University of Malang. Data collection techniques in this study were using a questionnaire. Analysis of research data used is descriptive statistics by calculating the central tendency. Implementation of supervision in SD Lab. ME is in the low category, whereas in SMP Lab. UM in the category of sufficient, as well as the results in high School Lab. The UM category is sufficient.
\end{abstract}

Keywords: informal supervision, quality of learning

\section{INTRODUCTION}

The key to improving school quality is improving the quality of learning. To improve the quality of learning, principals and teachers must know the professional aspects of teachers that must be improved. The teacher has a series of tasks in carrying out his role in learning, starting from compiling the syllabus, preparing lesson plans, preparing for teaching, managing classes, carrying out the learning process, managing children's behavior, making an assessment of children's learning outcomes and providing feedback, to reporting the results to parents.

The teacher has strengths and weaknesses in achieving his competence. Teachers need input and support from the principal, peers, and related parties to improve their professionalism. The principal can use the results of supervision to improve teacher competency. Supervision can be carried out through informal supervision, clinical supervision, formative teacher performance evaluation, and summative Teacher evaluation.

Managing by Walking About (MBWA) or blusukan means taking a few minutes each day to get around in the school area, greeting, and discussing with students, teachers and parents, as well as visiting class informally. The principal should schedule blusukan at different times each day. Including doing blusukan during recess, when students are outside the classroom, during study hours when students are studying in class, or during the morning before school hours or at school hours, when parents are at school. Do it for 10-15 minutes every day, then your school will look different. Supervision must produce a program plan to improve teacher professionalism (continuous professional development / CLA).

The Laboratory School of the State University of Malang, East Java Province, is an educational institution that seeks to facilitate the implementation of government regulations in the field of education and the interests of teachers in improving their professionalism, one of which is through continuing professional development. Malang State University Laboratory School, through UPT P2LP $\mathrm{UM}$, is fully aware that as one of the institutions responsible for the education management system at the university level, especially for the schools under its supervision ( 8 schools), continues to strive to improve the quality of the performance of the teaching staff, especially in the State University of Malang through the development and implementation of learning supervision.

The tasks of the UPT P2LP UM are: (1) coordinating the planning, implementation, monitoring and evaluation: the activity of studying / developing educational and learning innovations in the lab school, mess conducted by lecturers, students, partners and academic implementing units within mess; (2) coordinating the dissemination of innovation results / findings of study / development of education and learning to the community and related actors; (3) organizing academic activities: seminars, workshops, training and the like to increase the competence of teachers and managers of Lab Schools. UM; (4) providing administrative services to support the smooth and order study and development activities at UM Lab Schools conducted by lecturers, students, partners, and academic implementing units within the UM; and (5) provide support and facilitation for the BPLP Foundation to be more efficient and effective and accountable in managing and developing Lab Schools. UM.

Based on our research in 2018, one of the results is the implementation of curriculum and learning on learning supervision indicators which has the lowest value, namely 67.21 or 2.51 (Nurabadi, et. al., 2018). From the results of this study, researchers want to continue the next study with the theme of learning 
supervision that focuses on developing informal supervision models.

Schools have an important role in developing the quality of education. Education carried out must be able to shape and develop the potential that exists in schools and communities. Therefore quality education needs to be designed to be more interesting and in accordance with the context of schools and surrounding communities. Quality education is supported by quality learning, learning will be quality if carried out properly and all components in the school do their job properly. The findings of this study contribute to the development of educational management and educational leadership. The findings are expected to be valuable input for: (1) decision makers in the ranks of the P2LP unit of Malang State University in compiling school development plans based on an analysis of learning supervision needs by implementing sustainable professional development (PKB); (2) the principal, an informal supervision implementation model that is in line with the conditions of the teachers; and (3) academics in the fields of management, education administration and educational leadership as material for enrichment of insights and scientific studies, especially further research.

The concept of supervision needs to be clarified and emphasized. The term supervision in the literature must at least be understood in the context of: (1) inspection; (2) control; and (3) supervision. These three terms should not be confused, because they have different meanings. Supervision has the essence of professional compliance, which is professional compliance in the sense of guarantee that a professional performs his duties based on theories, concepts, results of empirical validation, and ethical principles (Sudjana, 2006).

Educational supervision is a function aimed at quality assurance of teaching and learning conducted by teachers. Academic supervision is the same as the concept of educational supervision. Educational supervision is often referred to as instructional supervision or instructional leadership, whose focus is on studying, assessing, improving, improving, and developing the quality of teaching and learning activities carried out together with teachers (individuals or groups) through the approach of guidance and consultation in the nuances of professional dialogue.

A measure of development to choose the right supervisory orientation. If all teachers are the same, it will be easy to determine the most effective supervision orientation. However, research on the influence of many oversight styles in view and behavior is confusing. Blumberg (1974) found that teachers were divided into two groups in feeling positive supervisory behavior. One group of the most positive teachers with supervision who listens to them by showing their ideas. This type of behavior is identified as a cooperative orientation.

However, other groups of teachers are most positive with supervision that mainly listens, encourages and explains their ideas. This combination of behavior is known as indirect orientation (Glickman, 1982). Generally positive assessments by teachers of the quality of their supervisory interpersonal relationships, show development when a teacher feels their supervisory behavior as heavy pressure in telling, encouraging, criticizing and in describing asking for little information, opinions etc. or when a teacher feels little supervision suppress it in telling and many in describing and asking.

Supervision is all the efforts made by supervisors to provide assistance to teachers in improving teaching and above to school personnel in improving the school system in improving the school system. If judging from the terms used, supervision comes from the English word that is supervision which means observing and directing a job. With this understanding, the supervisor will understand the scope and targets of his supervision. It is clear that supervision also has a very decisive role in achieving goals, as does the oversight function.

Supervisory activities concern human factors, because it is an important element in the administrative process, qualified personnel besides good leadership also determine whether the goals of the institution or organization are achieved. For this reason, continuous coaching is needed with a directed and systematic program for each personnel, so that the way it works, the capabilities it has, its attitude at work can be improved so as to obtain better work results. Supervision activities as an integral part of all organizational or institutional activities in an effort to achieve the maximum level of success. Supervision is carried out with the intention to create a situation that allows all personnel to grow and develop in accordance with the demands and needs of the organization and institution.

Supervision has the task of seeing clearly the problems that arise in influencing the learning situation and stimulating the teacher towards improvement efforts. Actually supervision is a form of supervision, seeing and assessing how far the plan is implemented, and are there any deviations or errors that occur in carrying out the plan. It is the duty of the principal and the appointed official to carry out the supervision that is obliged to make improvements and improvements to what has been done.

\section{METHODS}

This study uses a quantitative approach. Population is a group of elements, or groups of individuals who have certain qualities and characteristics that have been formulated as well as possible based on certain criteria to be of concern to researchers during conducting research (Sugiyono, 2011). The population and sample of this study were all school principals in UM laboratory schools totaling 3 schools, namely: (1) Laboratory Primary School consisting of 22 classes of 32 teachers; (2) Laboratory Junior High School is consisting of 22 classes 36; and (3) Laboratory High School consisting of 27 Class 51 teachers.

Research data collection was carried out using a questionnaire technique. The questionnaire technique is used to collect data into variables, sub variables, and research indicators. The use of the questionnaire technique as a data collection technique in this study is based on several considerations. The most important consideration is that the teacher as the respondent is the most knowledgeable source about himself or something related to him. Another consideration is that in terms of the level of efficiency the planning, implementation and use of the questionnaire technique is very easy, practical, 
and economical. On the other hand, researchers believe that respondents are human beings who are willing to provide honest information so that the data taken can be trusted as objective data. There are several types of questionnaires, namely closed questionnaire and open questionnaire. In this study, a closed questionnaire was used.

\section{RESULT}

\section{Data Description of SD Laboratory UM}

Based on the results of the UM Laboratory SD data description it is known: the average 79.69; standard deviation 6.93; maximum score of 92; minimum score of 69 ; range 23; and interval 6 . The description of the data frequency of UM Laboratory Primary School is presented in Table 1.

Table 1

Data Frequency Distribution of UM Laboratory Primary School

\begin{tabular}{|c|c|c|c|}
\hline Category & Interval & f & $\%$ \\
\hline Very low & $69-74$ & 8 & 25 \\
\hline Low & $75-80$ & 12 & 38 \\
\hline Enough & $81-86$ & 3 & 9 \\
\hline High & $87-92$ & 9 & 28 \\
\hline Very high & $93-98$ & 0 & 0 \\
\hline \multicolumn{2}{|c|}{ Total } & 32 & 100 \\
\hline
\end{tabular}

\section{Data Description of SMP Laboratory UM}

Based on the results of the description of the UM Laboratory SMP data it is known: the mean of 77.92 ; standard deviation of 7.99 ; maximum score of 92; minimum score of 67 ; range 25 ; and interval 6 . The description of the data frequency of UM Laboratory Middle School is presented in Table 2.

Table 2

Data Frequency Distribution of UM Laboratory Middle School

\begin{tabular}{|c|c|c|c|}
\hline Category & Interval & $\mathbf{f}$ & $\%$ \\
\hline Very low & $67-72$ & 11 & 30,56 \\
\hline Low & $73-78$ & 9 & 25,00 \\
\hline Enough & $79-84$ & 11 & 30,56 \\
\hline High & $85-90$ & 1 & 2,78 \\
\hline Very high & $91-96$ & 4 & 11,11 \\
\hline \multicolumn{2}{|c|}{ Total } & 36 & 100 \\
\hline
\end{tabular}

\section{Description Data of SMA Laboratory UM}

Based on the results of the description of the UM Laboratory High School data it is known: mean 79.04; standard deviation 7.51 ; maximum score of 92 ; minimum score of 67; range 25; and interval 6. The description of the data frequency of UM Laboratory High School is presented in Table 3 .

Table 3

Data Frequency Distribution of UM Laboratory High School

\begin{tabular}{|c|c|c|c|}
\hline Category & Interval & $\mathbf{f}$ & $\%$ \\
\hline Very low & $67-72$ & 11 & 21,57 \\
\hline Low & $73-78$ & 13 & 25,49 \\
\hline Enough & $79-84$ & 14 & 27,45 \\
\hline High & $85-89$ & 6 & 11,76 \\
\hline Very high & $90-95$ & 7 & 13,73 \\
\hline \multicolumn{2}{|c|}{ Total } & 51 & 100 \\
\hline
\end{tabular}

\section{DISCUSSION}

Blusukan or managing by walking about (MBWA) means taking a few minutes each day to get around in the school area, greeting, and discussing with students, teachers, and parents, as well as visiting class informally. The principal should schedule blusukan at different times each day. Including doing blusukan during recess, when students are outside the classroom, during study hours when students are studying in class, or during the morning before school hours or at school hours, when parents are at school. Do it for 10-15 minutes every day, then your school will look different.

Daily visits to classes should not be 'formal observation'. Daily visits to this class should not interfere with learning activities in the classroom, do not interfere with the teacher who is teaching and students who are learning. Daily visits to the class can give the principal an idea of what is really happening in the classroom and how the teaching and learning process is happening. If there are things that need to be followed up (for example, there are teachers who have difficulty regulating children's behavior in class), the principal can immediately find a way out.

Today's informal supervision has a strategic role in improving performance and professional development within the framework of staff coaching. Farber and Hazanov (2014) sought to overcome a significant gap in the research literature, namely by conducting a survey of 146 teachers through an online self-report questionnaire about their experiences with "informal supervision". They ask teachers: who they are most likely to share clinical information with (for example, colleagues in training programs, leaders, friends, family members, psychotherapists and other important people); what kind of information they share with these people; why they seek informal supervision; how informal supervision advice or support seems useful; and whether teachers share their experiences with their supervisors and senior teachers.

The results of research at the Laboratory of State University of Malang University showed different results at each level, at the SD Lab. UM obtained informal supervision results in the low category, whereas in SMP Lab. UM in the category of sufficient, as well as the results in high school Lab. UM shows sufficient conditions. From these results it can be concluded that the implementation of informal supervision is still not good, which means that supervision tends to be done formally.

Supervisors most often use informal supervision, because the informal supervision they choose is appropriate and supervisors are broad-minded, they need (personal) guarantees. Their supervisors are knowledgeable about specific aspects of a particular clinical case, and they need more than one opinion about this case. Importantly, teachers are happy with the informal supervision model, because they do not agree with formal supervision, because they feel intimidated by their supervisor, or feel that their supervisor is too judgmental. When asked what type of clinical situation causes the teacher to seek informal supervision, of the 15 possible items, the most supported are feeling stuck, feeling wrong making clinical mistakes, and feeling challenged by work. Regarding the usefulness of experienced informal supervision, teachers find informal supervision very helpful in their clinical work and emotional well-being. Importantly, teachers tend not to 
share their informal supervision experience with their formal supervisors.

Farber and Hazanov (2014) findings show that teachers like informal supervision, especially with their inner work colleagues. When teachers feel strongly challenged, stagnant, or feel as though they have made a critical mistake, they seek informal supervision from individuals they consider intelligent and broad-minded, both for clinically savvy knowledge and emotional support (Farber \& Hazanov, 2014). A study by Golia and McGovern (2013) explores ways training programs can incorporate a peer model into their current practice. Farber and Hazanov (2014) found that the peer model helped normalize and reduce teachers' anxiety and feelings of inadequacy, while allowing teachers to build trust in clinical judgment and skills through conversations with peers. Teachers report that discussing teaching material with fellow teachers in their school without the presence of a formal supervisor encourages a safer and non-intimidating environment to explore and process difficult problems that arise in learning. This is the argument that must be considered by a supervisor.

\section{CONCLUSION}

In general, the implementation of supervision in the UM Laboratory School in the sufficient category, in the SD Lab. UM obtained informal supervision results in the low category, whereas in SMP Lab. UM in the category of sufficient, as well as the results in high school Lab. UM shows sufficient conditions.

\section{REFERENCES}

[1] Echols, J. M., \& Shadily, H. 1975. Kamus InggrisIndonesia. Jakarta: Gramedia.

[2] Farber, B. A., \& Hazanov, V. 2014. Informal Sources of Supervision in Clinical Training. Journal of Clinical Psychology, 70(11), 1062-1072.

[3] Ghozali, I. 2007. Aplikasi Analisis Multivariate dengan Program SPSS. Semarang: Badan Penerbit Universitas Diponegoro.
[4] Golia, G. M., \& McGovern, A. R. 2013. If You Save Me, I'll Save You: The Power of Peer Supervision in Clinical Training and Professional Development. British Journal of Social Work, 67(2), 138-145.

[5] Gorton, R. A., \& Schnelder, G. T. 1991. School Based Leadership: Challenges and Opportunities. New York: WCB Publisher.

[6] Hadi, S. 2001. Statistik. Yogyakarta: Andi.

[7] Hardjono, R. 2002. Kamus Populer Inggris-Indonesia. Jakarta: Gramedia Pustaka Utama.

[8] Hill, C. E., Knox, S., Thompson, B. J., Williams, E. N., Hess, S. A., \& Ladany, N. 2005. Consensual Qualitative Research: An Update. Journal of Counseling Psychology, 52(2), 196.

[9] Hill, C. E., Thompson, B. J., \& Williams, E. N. 1997. A Guide to Conducting Consensual Qualitative Research. The Counseling Psychologist, 25(4), 517-572.

[10] Kuncoro, E. A., \& Riduwan. 2007. Cara Menggunakan dan Memakai Analisis Jalur (Path Analysis). Bandung: Alfabeta.

[11] Managing Basic Education. 2008. Asyik Belajar dengan PAKEM. Jakarta: MBE.

[12] Nazir, M. 2005. Metode Penelitian. Bogor: Ghalia Indonesia.

[13] Nurabadi, Ahmad., Sucipto, Juharyanto, dan Gunawan, Imam. 2018. The Implementation of Education Management Standards in the School Laboratory State University of Malang for Improving Educational Quality. 3rd International Conference on Educational Management and Administration (CoEMA 2018).

[14] Stoop, E. 1981. Handbook of Educational Administration: A Guide for the Practitioner. Boston: Allyn and Bacon, Inc.

[15] Sugiyono. 2011. Metode Kuantitatif Kualitatif dan R\&D. Bandung: Alfabeta.

[16] Suparmoko. 1988. Metode Penelitian Praktis. Yogyakarta: BPFE.

[17] Usman, H. 2010. Manajemen: Teori, Praktik, dan Riset Pendidikan. Jakarta: Bumi Aksara.

[18] Yeager, W. A. 1985. Administration and the Pupil. New York: Harper and Brother. 